0192-0561(95)00015-1

\title{
LEVELS OF SOLUBLE INTERCELLULAR ADHESION MOLECULE 1, EICOSANOIDS AND CYTOKINES IN ASCITES OF PATIENTS WITH LIVER CIRRHOSIS, PERITONEAL CANCER AND SPONTANEOUS BACTERIAL PERITONITIS
}

\author{
W. M. PRUIMBOOM,* D. J. BAC, ${ }^{\dagger}$ A. P. M. VAN DIJK,* I. M. GARRELDS,* C. J. A. M. TAK,* \\ I. L. BONTA,* J. H. P. WILSON ${ }^{\dagger}$ and F. J. ZIJLSTRA*
}

\begin{abstract}
*Department of Pharmacology, Erasmus University, P. O. Box 1738, 3000 DR Rotterdam, The Netherlands; and ${ }^{\dagger}$ Department of Internal Medicine II, University Hospital Dijkzigt Rotterdam, The Netherlands
\end{abstract}

(Received in final form 3 January 1995)

\begin{abstract}
The levels of the eicosanoids leukotriene $B_{4}$, prostaglandin $E_{2}$, prostacycline and thromboxane $B_{2}$, the cytokines interleukin- $1 \beta$, interleukin -6 and tumour necrosis factor- $\alpha$ and soluble intercellular adhesion molecule 1 were measured in ascites and plasma samples of patients with liver cirrhosis (53), peritoneal cancer (26) and spontaneous bacterial peritonitis (10) to assess their value as a possible diagnostic and prognostic parameter in the course of the disease. Soluble intercellular adhesion molecule 1 , of the eicosanoids prostaglandin $\mathrm{E}_{2}$ and leukotriene $B_{4}$, and the protein concentration in ascites were all significantly elevated in ascites of patients with peritoneal cancer in comparison to ascites of patients with liver cirrhosis. In ascites of patients with spontaneous bacterial infection interleukin- 6 concentration was significantly elevated and the protein concentration was significantly lower in comparison to the other two groups. None of these parameters, however, seems to be of practical use as a diagnostic parameter, as there is an overlap between all the levels of these mediators in ascites of liver cirrhosis, peritoneal cancer and spontaneous bacterial peritonitis group. Soluble intercellular adhesion molecule 1 levels were much higher in plasma than in ascites, in contrast to interleukin-6 levels which were much higher in ascites than in plasma. Soluble intercellular adhesion molecule 1 in ascites correlated with soluble intercellular adhesion molecule 1 in plasma $(r=0.6926, P=0.0001)$. Soluble intercellular adhesion molecule 1 , interleukin- 6 and the number of polymorphonuclear cells in peritoneal fluid correlated during episodes of infection in patients with a peritonitis. For this reason soluble intercellular adhesion molecule $l$ and interleukin- 6 could be of prognostic value for patients with peritonitis.
\end{abstract}

Keywords : soluble ICAM-1, interleukin-6, ascites, liver cirrhosis, peritoneal cancer, spontaneous bacterial peritonitis.

Ascites is the accumulation of fluid in the peritoneal cavity. The main causes of ascites are liver cirrhosis, malignancies involving the peritoneum and inflammatory processes. Early diagnosis of the probable cause of the ascites is useful for guiding further investigation and treatment (Bac et al., 1993a). Ascites may be complicated by bacterial infection, a condition known as spontaneous bacterial peritonitis (SBP). SBP has a high mortality unless diagnosed and treated at an early stage (Bac et al., 1993b). Ascites of all causes contain inflammatory cells, mainly macrophages $(M \phi)$, which produce inflammatory mediators. As the pattern of mediators produced by inflammatory cells depends in part on the stimulus and on the stage of inflammation, we decided to measure in ascites a wide variety of inflammatory mediators or products of inflammation to determine whether the different causes of ascites were associated with specific patterns of inflammatory mediators in ascites. Based on prior work in which we characterized production of inflammatory mediators by human peritoneal macrophages (hp-M $\phi$; Pruimboom et al., 1994) we measured arachidonic acid products, several pro-inflammatory cytokines, and a soluble form of an adhesion molecule. The lipoxygenase product leukotriene $\mathrm{B}_{4}\left(\mathrm{LTB}_{4}\right.$; Lewis \& Austen, 1984) and the cyclooxygenase products prostaglandin $E_{2}\left(P_{2} E_{2}\right)$, thromboxane $A_{2}\left(T_{X A}\right)$ and prostacycline [PGI detected as 6-keto prostaglandin $\mathrm{F}_{10}$ $\left(6 \mathrm{kPGF}_{1 \alpha}\right)$; Goldyne, 1987] were measured as these are products of hp-M $\phi$ (Pruimboom et al., 1994). 
We also measured the pro-inflammatory cytokines

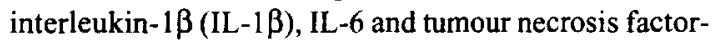
$\alpha$ (TNF- $\alpha$, Arai et al., 1990; Oppenheim et al., 1991), which are also produced by hp-M $\phi$ (Pruimboom et al., 1994).

In addition, we measured the soluble intercellular adhesion molecule 1 (sICAM-1). ICAM-1 plays a crucial role in the adhesion and migration of inflammatory cells, and is a single-chain membrane-bound glycoprotein (Springer, 1990) which is expressed on endothelial and other cells (Springer, 1990; Dustin et al., 1986; Temponi et al., 1988). Expression of ICAM- 1 is up-regulated by the cytokines IL-1, TNF- $\alpha$ and interferon-gamma (IFN- $\gamma$ ) (Dustin et al., 1986; 1986; Temponi et al., 1988; Pober et al., 1986; Beekhuizen et al., 1991) and also by the chemoattractants $\mathrm{LTB}_{4}$ and $\mathrm{C5a}$ (Pattaroyo, 1989). Expression of ICAM-1 on tissue leads to the release of a soluble form into the circulation. The biological function of this soluble form of ICAM-1 is not yet clear and little is known about the relation between expression of ICAM- 1 on tissue and its soluble form. Soluble isoforms of adhesion molecules can be found in the circulation of normal humans (Rothlein et al., 1991).

Although there are publications on IL- 6 and TNF- $\alpha$ in ascites, especially during SBP (Andus et al., 1992; Pelletier et al., 1992; Propst et al., 1993; Deviere et al., 1991), we are not aware of any reports on ascitic eicosanoid and ascitic sICAM-1 levels. Soluble ICAM-1 in plasma or serum (Rothlein et al., 1991; Adams et al., 1992; Banks et al., 1993; Sfikakis et al., 1993; Sharief et al., 1992; Harning et al., 1991; Nouri-Aria et al., 1993) and the cytokines IL-1, IL-6 and TNF- $\alpha$ in plasma, serum or ascites (Andus et al., 1992; Pelletier et al., 1992; Sharief et al., 1992; Khoruts et al., 1991; Byl et al., 1993; Tilg et al., 1992; McClain et al., 1986; Felver et al., 1990) have been found to be elevated in patients with different diseases including malignancies and liver cirrhosis. Therefore we measured the levels of SICAM-1, the representative eicosanoids $\mathrm{LTB}_{4}, \mathrm{PGE}_{2}, \mathrm{PGI}_{2}$ and $\mathrm{TXB}_{2}$ and the pro-inflammatory cytokines IL-1 $\beta$, IL- 6 and TNF $-\alpha$ in ascites of patients with liver cirrhosis, peritoneal cancer and SBP to increase our understanding of inflammatory mediators involved in peritoneal inflammation, to determine whether these mediators showed a specific disease-related pattern and whether this pattern could be of diagnostic and prognostic value.

Simultaneously, we measured the same parameters in blood samples of these patients to determine whether there was a close correlation between ascites and plasma values.

\section{EXPERIMENTAL PROCEDURES}

\section{Patients}

Eighty-nine ascites samples were obtained. Some patients were drained several times during the period in which samples were collected. There was usually a period of several weeks between samples (a total of 63 patients were drained). These samples were divided into three groups: the liver cirrhosis group [number of samples $=53$, sex $(M / F)=33 / 20$, age $($ range $)=$ $58(27-82)]$, the peritoneal cancer group [number of samples $=26$, sex $(M / F)=18 / 8$, age $($ range $)=$ $61(37-81)$ ] and the SBP group [number of samples $=10$, sex $(M / F)=7 / 3$, age $($ range $)=48(22-59)$ ] .

A paticnt with ascites was classificd as having SBP if the number of polymorphonuclear cells (PMN) was higher then $0.25 \times 10^{9}$ cells $/ 1$ in the ascites and the bacterial culture of the ascitic fluid was positive, or in case the culture was negative, the PMN count in the ascites should be higher then $0.5 \times 10^{9}$ cells $/ 1$ (Bac et al., 1993a). A patient with renal failure on continuous ambulatory peritoneal dialysis (CAPD) was classified as having a peritonitis if the number of PMN was higher then $0.10 \times 10^{9}$ cells $/ 1$ in the dialysates and the bacterial culture was positive (Vas, 1989).

In the liver cirrhosis group there were 29 samples obtained from patients with alcoholic liver cirrhosis, 13 samples from patients with hepatitis $B$ or $C$ virus induced cirrhosis, three samples from patients with primary biliary cirrhosis or sclerosing cholangitis, five samples from patients with Budd Chiari and three samples from patients with other diseases.

Of the malignancy-related ascites group all patients had metastized disease. Eight samples were obtained from patients with colon carcinoma, seven samples from patients with pancreatic carcinoma, three samples from patients with liver carcinoma, two samples from patients with peritoneal mesothelioma, two samples from patients with gastric carcinoma, one sample from a patient with lung carcinoma, one sample from a patient with a sarcoma and two samples from patients with an unknown primary source.

In the SBP group four samples were obtained from a patient with hepatitis $B$ virus-induced cirrhosis, and this patient had a Staphylococcus epidermidis infection in the ascites (PMN number varied between $0.5 \times 10^{9}$ and $4.2 \times 10^{9}$ cells $/ 1$ ), three samples were obtained from a patient with a pancreas carcinoma and a portal vein thrombosis, and this patient had a Klebsiella infection in the ascites (PMN number varied between $0.6 \times 10^{9}$ and $\left.15.6 \times 10^{9} \mathrm{cells} / \mathrm{l}\right)$, two samples were obtained from patients with liver cirrhosis, one of these patients had an Escherichia coli infection in the ascites $\left(4.3 \times 10^{9}\right.$ 

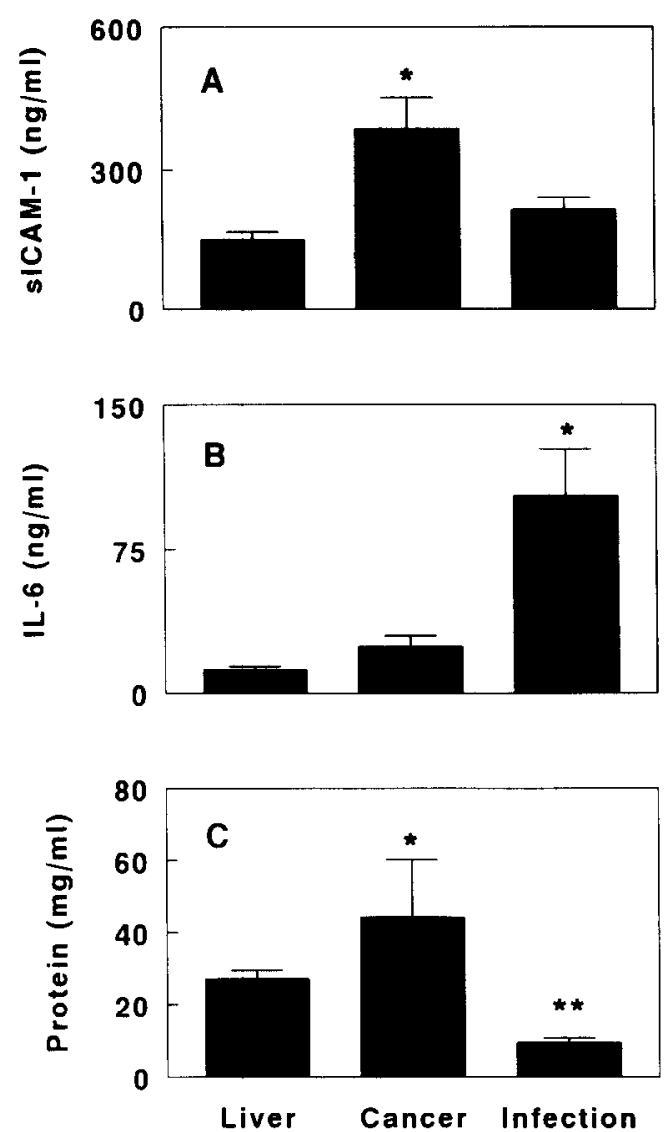

Fig. 1. (A) Soluble ICAM- 1 concentration ( $\mathrm{ng} / \mathrm{ml}$ ) in ascites of patients with ascites due to liver cirrhosis (liver, $n=53$ ), peritoneal cancer (cancer, $n=26$ ) and SBP (infection, $n=10$ ). (B) Interleukin-6 concentration $(\mathrm{ng} / \mathrm{ml})$ in ascites of patients with ascites due to liver cirrhosis (liver, $n=53$ ), peritoneal cancer (cancer, $n=26$ ) and SBP (infection, $n=10$ ). (C) Protein concentration $(\mathrm{mg} / \mathrm{ml})$ in ascites of patients with ascites due to liver cirrhosis (liver, $n=46$ ), peritoneal cancer (cancer, $n=25$ ) and SBP (infection, $n=7$ ). *Significantly higher than the other two groups $(P<0.05)$; **Significantly lower than the other two groups.

PMN/l), the other patient had a Streptococcus mitis infection in the blood, the ascitic culture of this patient was negative ( $7.8 \times 10^{9} \mathrm{PMN} / 1$ in ascites). One sample was obtained from a patient with an acute liver failure and an Escherichia coli infection in the ascites $\left(10.5 \times 10^{9} \mathrm{PMN} / 1\right)$.

In 34 of these patients with ascites, blood (24 samples from the liver cirrhosis group, six samples from the cancer group and four samples from the SBP group) was collected in EDTA-tubes on the same day or the day after ascites drainage. Blood was also obtained from 17 healthy volunteers [sex $(\mathrm{M} / \mathrm{F})=$ $12 / 5$, age $($ range $)=29(23-40)]$.
From two patients $[\operatorname{sex}(\mathrm{M} / \mathrm{F})=1 / 1$, age (range) $=49$ (41-57)] with renal failure on continuous ambulatory peritoneal dialysis (CAPD), the drained dialysates were collected during and after an episode of peritoneal bacterial infection. The first CAPD patient had a Klebsiella infection. The number of PMN varied between $0.1 \times 10^{9}$ and $3.8 \times 10^{9} \mathrm{PMN} / 1$. The second CAPD patient had Enterococcus faecalis infection. The number of PMN varied between $0.2 \times 10^{9}$ and $1.4 \times 10^{9} \mathrm{PMN} / \mathrm{l}$.

\section{Assays}

The ascites, dialysates and blood were centrifuged at $1500 \mathrm{~g}$ directly after withdrawal. The centrifuged ascites, dialysates and plasma were stored at $-80^{\circ} \mathrm{C}$ until they were analysed. Soluble ICAM- 1 , TNF- $\alpha$, IL- $1 \beta$ and IL- 6 were determined in the centrifuged ascites and plasma using commercially available ELISA kits (sICAM-1, British Biotechnology Products, U.K., sensitivity $2.5 \mathrm{ng} / \mathrm{ml}$; TNF- $\alpha$, Eurogenetics, U.S.A., sensitivity $10 \mathrm{pg} / \mathrm{ml}$; IL-1 $\beta$, Eurogenetics, U.S.A., sensitivity $2 \mathrm{pg} / \mathrm{ml}$; IL-6, Hycult, The Netherlands, sensitivity $2 \mathrm{pg} / \mathrm{ml}$ ).

$\mathrm{LTB}_{4}, \mathrm{PGE}_{2}, 6 \mathrm{kPGF}_{1 \alpha}$ and $\mathrm{TXB}_{2}$ were determined by radioimmunoassays (Antibodies, Advanced Magnetics, U.S.A., ${ }^{3}$ H-Antigen, Amersham, U.K.; standards, Sigma, U.S.A.) in centrifuged ascites and plasma which were passed through Sep Pak $C_{18}$ cartridges (Water Assoc., U.S.A.).

In the dialysates only sICAM-1 and IL-6 were determined. Protein concentrations in the ascites and plasma were determined using the pyrogallol-redmolybdate(IV) method (Instruchemie, The Netherlands).

\section{Statistical analysis}

Data are expressed as the mean \pm S.E.M. Data were statistically analysed with ANOVA followed by Student's $t$-test. The correlations were determined by the Pearson Correlation test. Data were considered significant when $P<0.05$.

\section{RESULTS}

Soluble ICAM-1, cytokine and eicosanoid concentrations in ascites

The soluble ICAM-1 concentration was significantly elevated in ascites of patients with peritoneal cancer ( $385 \pm 66 \mathrm{ng} / \mathrm{ml}, n=26$ ) compared to the conceritration 
Table 1. Eicosanoid concentration in ascites of patients with liver cirrhosis, peritoneal cancer and SBP

\begin{tabular}{lccc}
\hline Eicosanoids & $\begin{array}{c}\text { Liver cirthosis } \\
(n)\end{array}$ & $\begin{array}{c}\text { Peritoneal cancer } \\
(n)\end{array}$ & $\begin{array}{l}\text { SBP } \\
(n)\end{array}$ \\
\hline $\mathrm{LTB}_{4}$ & $21 \pm 5.4$ & $193 \pm 67^{* *}$ & $\mathrm{nd}^{*}$ \\
$(\mathrm{pg} / \mathrm{ml})$ & $(47)$ & $(26)$ & $(10)$ \\
$\mathrm{PGE}$ & $27 \pm 3.2^{*}$ & $122 \pm 27^{* * *}$ & $79 \pm 20.7$ \\
$(\mathrm{pg} / \mathrm{ml})$ & $(47)$ & $(26)$ & $(10)$ \\
$6 \mathrm{kPGF}$ & $145 \pm 62$ & $359 \pm 110^{* * * *}$ & $113 \pm 38$ \\
$\left(\mathrm{pg} / \mathrm{ml}^{*}\right.$ & $(47)$ & $(26)$ & $(10)$ \\
$\mathrm{TXB}$ & $57 \pm 8.1$ & $70 \pm 9.4$ & $53 \pm 3.2$ \\
$(\mathrm{pg} / \mathrm{ml})$ & $(46)$ & $(26)$ & $(8)$ \\
\hline
\end{tabular}

Data are means \pm S.F.M

nd, Not detectable; $n$, number of samples.

*Significantly lower than the other two groups $(P<0.05)$.

**Significantly higher than the other two groups $(P<0.05)$.

***Significantly higher than the liver cirrhosis group $(P<0.05)$.

****Significantly higher than the SBP group $(P<0.05)$.

Table 2. Soluble ICAM-1, cytokine and eicosanoid concentration in plasma of patients with liver cirrhosis, peritoneal cancer and SBP and in plasma of controls

\begin{tabular}{|c|c|c|c|c|}
\hline Mediators & $\begin{array}{l}\text { Liver cirrhosis } \\
\qquad(n)\end{array}$ & $\begin{array}{l}\text { Peritoneal cancer } \\
(n)\end{array}$ & $\begin{array}{r}\text { SBP } \\
(n)\end{array}$ & $\begin{array}{c}\text { Plasma control } \\
(n)\end{array}$ \\
\hline sICAM-1 & $781 \pm 141$ & $781 \pm 367$ & $1204 \pm 271$ & $228 \pm 24^{*}$ \\
\hline$(\mathrm{ng} / \mathrm{ml})$ & (24) & (5) & (3) & (17) \\
\hline IL-6 & $1191 \pm 358$ & $420 \pm 215$ & $1736 \pm 394$ & $\mathrm{nd}^{*}$ \\
\hline$(\mathrm{pg} / \mathrm{ml})$ & (24) & (6) & (4) & (17) \\
\hline IL $-1 \beta$ & nd & nd & nd & nd \\
\hline$(\mathrm{pg} / \mathrm{ml})$ & (17) & (6) & (4) & (17) \\
\hline TNF- $\alpha$ & nd & nd & nd & nd \\
\hline$(\mathrm{pg} / \mathrm{ml})$ & (17) & (6) & (4) & (17) \\
\hline $\begin{array}{l}\mathrm{LTB}_{4} \\
(\mathrm{pg} / \mathrm{ml})\end{array}$ & $\begin{array}{l}22 \pm 16.3 \\
(23)\end{array}$ & $\begin{array}{l}14 \pm 14.1 \\
(6)\end{array}$ & $\begin{array}{c}54 \pm 54.6 \\
(4)\end{array}$ & $\begin{array}{l}\text { nd } \\
(17)\end{array}$ \\
\hline $\begin{array}{l}\mathrm{PGE}_{2} \\
(\mathrm{pg} / \mathrm{ml})\end{array}$ & $\begin{array}{c}67 \pm 21.1 \\
(23)\end{array}$ & $\begin{array}{l}68 \pm 32.1 \\
(6)\end{array}$ & $\begin{array}{c}52 \pm 48.0 \\
(4)\end{array}$ & $\begin{array}{c}70 \pm 13.0 \\
(16)\end{array}$ \\
\hline $\begin{array}{l}6 \mathrm{KPGF}_{1 \alpha} \\
(\mathrm{pg} / \mathrm{mll})\end{array}$ & $\begin{array}{c}104 \pm 67.4 \\
(23)\end{array}$ & $\begin{array}{c}14 \pm 14.3 \\
(6)\end{array}$ & $\begin{array}{c}6.7 \pm 4.7 \\
(4)\end{array}$ & $\begin{array}{c}8.8 \pm 1.4 \\
(16)\end{array}$ \\
\hline $\begin{array}{l}\mathrm{TXB} \\
(\mathrm{pg} / \mathrm{ml})\end{array}$ & $\begin{array}{c}256 \pm 126 \\
(17)\end{array}$ & $\begin{array}{c}141 \pm 51 \\
(6)\end{array}$ & $\begin{array}{c}127 \pm 32 \\
(2)\end{array}$ & $\begin{array}{c}153 \pm 67 \\
(14)\end{array}$ \\
\hline
\end{tabular}

*Significantly lower than the three patient groups $(P<0.05)$.

Data are means \pm S.E.M.

$n$, number of samples.

nd, Not detectable.

of sICAM-1 in ascitic fluid of patients with liver cirrhosis $(151 \pm 16 \mathrm{ng} / \mathrm{ml}, n=53, P=0.0000)$ and SBP $(215 \pm 27 \mathrm{ng} / \mathrm{ml}, n=10, P=0.0284)$. There was no significant difference between the concentrations in ascites from patients with liver cirrhosis and SBP (Fig. 1A).

The IL- 6 concentration was significantly elevated in ascites of patients with SBP $(103 \pm 24 \mathrm{ng} / \mathrm{ml}, n=10)$ compared to the concentration of IL- 6 in ascites of patients with liver cirrhosis $(12 \pm 1.8 \mathrm{ng} / \mathrm{ml}, n=53$,
$P=0.0000)$ and peritoneal cancer $(24 \pm 5.7 \mathrm{ng} / \mathrm{ml}$, $n=26, P=0.0000$; Fig. 1B).

The ascites protein concentration was significantly lower in SBP $(10 \pm 1.6 \mathrm{mg} / \mathrm{ml}, n-7, P=0.0104)$ than in the liver cirrhosis group $(26 \pm 2.4 \mathrm{mg} / \mathrm{ml}, n=46)$ and peritoneal cancer group $(44 \pm 2.6 \mathrm{mg} / \mathrm{ml}, n=25$, $P=0.0000$ ). Ascites protein levels are significantly higher $(P=0.0000)$ in peritoneal cancer than in the other two groups (Fig. 1C).

Of the eicosanoids, $\mathrm{LTB}_{4}$ and $\mathrm{PGE}_{2}$ concentrations 
Table 3. sICAM-1, cytokine and eicosanoid concentration in ascites and plasma of patients (grouped all together) with liver cirrhosis, peritoneal cancer and SBP

\begin{tabular}{lcc}
\hline Mediators & Ascites $(n)$ & Plasma $(n)$ \\
\hline sICAM-1 & $227 \pm 24$ & $820 \pm 122^{*}$ \\
$\mathrm{ng} / \mathrm{ml}$ & $(89)$ & $(32)$ \\
$\mathrm{IL}-6$ & $26 \pm 4.4^{* *}$ & $1 \pm 0.3$ \\
$\mathrm{ng} / \mathrm{ml}$ & $(89)$ & $(34)$ \\
$\mathrm{IL}-1 \beta$ & $10 \pm 2.7$ & $\mathrm{nd}$ \\
$\mathrm{pg} / \mathrm{ml}$ & $(59)$ & $(25)$ \\
$\mathrm{TNF}-\alpha$ & $65 \pm 24.4^{* *}$ & $\mathrm{nd}$ \\
$\mathrm{pg} / \mathrm{ml}$ & $(78)$ & $(24)$ \\
$\mathrm{LTB}$ & $72 \pm 22.7$ & $25 \pm 13.0$ \\
$\mathrm{pg} / \mathrm{ml}$ & $(84)$ & $(33)$ \\
$\mathrm{PGE}$ & $63 \pm 10.0$ & $65 \pm 16.4$ \\
$\mathrm{pg} / \mathrm{ml}$ & $(84)$ & $(33)$ \\
$6 \mathrm{kPGF}$ & $206 \pm 50$ & $76 \pm 47.3$ \\
$\mathrm{pg} / \mathrm{ml}$ & $(84)$ & $(33)$ \\
$\mathrm{TXB}$ & $61 \pm 5.5$ & $218 \pm 86.2$ \\
$\mathrm{pg} / \mathrm{ml}$ & $(81)$ & $(25)$ \\
\hline
\end{tabular}

Data are means \pm S.E.M.

nd, not detectable; $n$, number of samples.

*Significantly higher than the ascites values $(P<0.05)$.

**Significantly higher than the plasma values $(P<0.05)$.

were significantly higher in ascites of patients with peritoneal cancer $(n=26)$ than in the liver cirrhosis group $(n=47)$, and ascites $\mathrm{LTB}_{4}$ and $6 \mathrm{kPGF}_{1 \alpha}$ concentrations of peritoneal cancer were significantly increased in comparison to SBP ( $n=10$, Table 1). The $\mathrm{LTB}_{4}$ concentration in ascites of patients with SBP, and the $\mathrm{PGE}_{2}$ concentration in ascites of patients with liver cirrhosis were significantly lower in comparison with the other two groups.

Soluble ICAM-1, cytokine and eicosanoid concentrations in plasma

In Table 2 the plasma levels of sICAM-1, cytokine and eicosanoid concentrations per patient group and controls were compared. No significant differences were seen between the three patient groups. Soluble ICAM-1 and IL- 6 concentrations in plasma of the patients were significantly elevated in comparison to the controls. IL- $1 \beta$ and TNF- $\alpha$ were not detectable in plasma of patients; IL-1 $\beta$, IL- 6 , TNF- $\alpha$ and LTB $_{4}$ were not detectable in control plasma.

Comparison between the sICAM-1, cytokine and eicosanoid concentrations in ascites and plasma

As we had only a small number of plasma samples from the peritoneal cancer and SBP groups and there were no significant differences between the plasma levels of the three patient groups, all the plasma samples

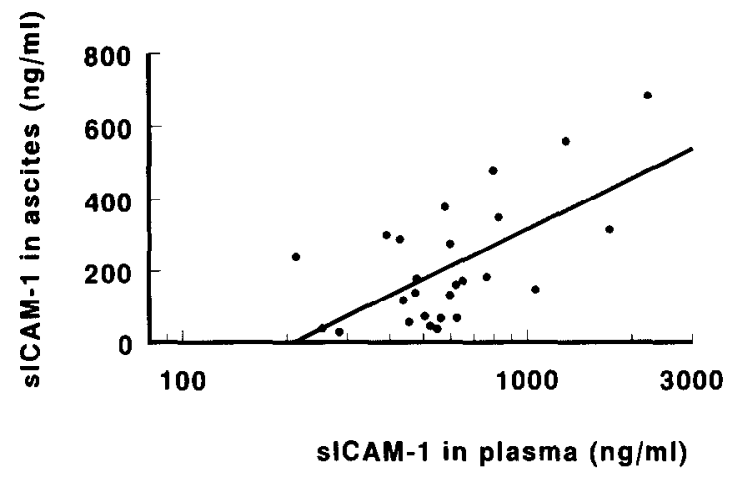

Fig. 2. Correlation between soluble ICAM-1 in ascites and plasma of patients with ascites due to liver cirthosis, peritoneal cancer and SBP $(r=0.6926, P=0.0001, n=27)$.

of patients were compared with the ascites samples, without subdivision, as calculated and shown in Table 3. There were differences between plasma and ascites values: sICAM-1 concentration was much higher in plasma, while IL- 6 and TNF- $\alpha$ concentrations were higher in ascites (Table 3 ).

There was a good relation between ascites SICAM-1 and plasma sICAM-1 $(r=0.6926, P=0.0001, n=27$, Fig. 2); for the other metabolites there was no correlation.

\section{Soluble ICAM-1 and IL-6 concentrations during peritonitis}

In two patients with SBP, the ascites was drained several times (patient 1 : five times, days $0,25,28,32$, 38 , and patient 2 : four times, days $0,6,18,24$ ) over 5-6 weeks. For both these patients sICAM-1 and IL-6 concentrations in ascites changed during this period: patient 1 had no SBP on the first day (day 0 ) of drainage (negative culture, $0.1 \times 10^{9} \mathrm{PMN} / \mathrm{l}$ ). The sICAM-1 and IL-6 concentrations in the ascites were low $(77 \mathrm{ng} / \mathrm{ml}$ sICAM-1 and $1 \mathrm{ng} / \mathrm{ml} \mathrm{IL-6).} \mathrm{On} \mathrm{day} 25$ the patient had a subtotal hepatic resection. After this operation the number of PMN $\left(1.7 \times 10^{9} \mathrm{PMN} / 1\right)$, sICAM-1 $(190 \mathrm{ng} / \mathrm{ml})$ and IL-6 $(72 \mathrm{ng} / \mathrm{ml})$ had increased in the ascites. A Staphylococcus epidermidis infection was diagnosed on day 28 in the ascites $\left(0.5 \times 10^{9} \mathrm{PMN} / 1\right.$, $242 \mathrm{ng} / \mathrm{ml}$ sICAM-1, $56 \mathrm{ng} / \mathrm{ml}$ IL-6). During the peritonitis SICAM-1 and IL- 6 concentrations peaked at day 32 (316 ng/ml sICAM-1, $119 \mathrm{ng} / \mathrm{ml}$ IL-6, $4.2 \times 10^{9}$ $\mathrm{PMN} / 1$ ). Antibiotics were given after day 32 , after which the sICAM-1 and IL-6 concentrations decreased (195 ng/ml sICAM, 79 ng/ml IL-6, $2.2 \times 10^{9} \mathrm{PMN} / 1$, Fig. 3A).

Patient 2 had a Klebsiella peritonitis on the first day 
(A)

Patient 1

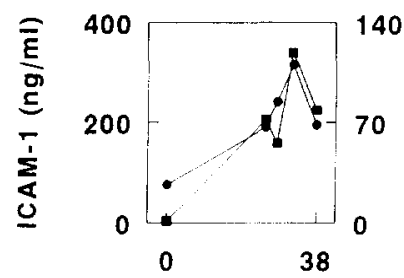

Time (days)
(B)

Patient 2

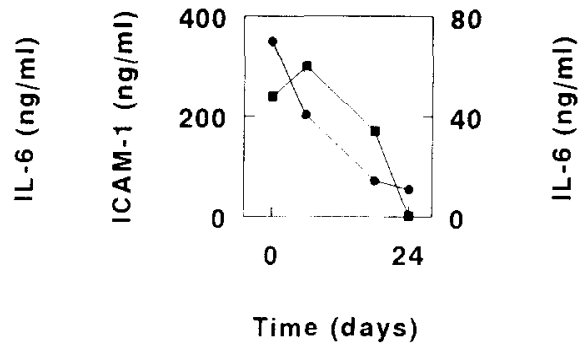

Fig. 3. Soluble ICAM01 (O) and IL-6 ( $)$ concentrations $(\mathrm{ng} / \mathrm{ml})$ in ascites of two patients with SBP. (A) Patient 1 had no SBP on day 0 of drainage. The patient was operated on day 25, and a Staphylococcus epidermidis infection started after this operation. Antibiotics were given after day 32. (B) Patient 2 had a SBP on the first day of drainage (Klebsiella infection). Antibiotics were given for several weeks. At day 24 the patient was free of infection.

(A)

Patient 3

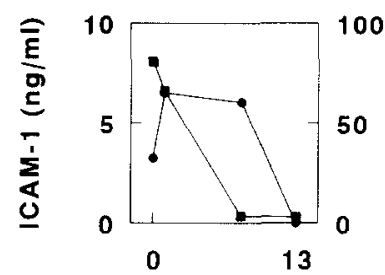

Time (days)
(B)

Patient 4

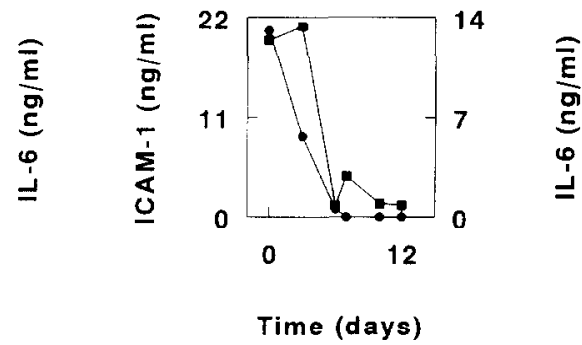

Fig. 4. Soluble ICAM-1 (O) and IL-6( $(\mathbf{)})$ concentrations $(\mathrm{ng} / \mathrm{ml})$ in drained dialysates of two CAPD patients during an episode of peritoneal infection. (A) Patient 3 had a peritonitis (Klebsiella) on day 0 and no antibiotics had yet been given. On day 1 antibiotics were given. On day 13 the patient was free of infection. (B) Patient 4 had a peritonitis (Enteroccus faecalis) on day 0 and no antibiotics had yet been given. On day 12 the patient was free of infection.

of drainage. In the ascites of this patient the sICAM-1 and IL- 6 concentrations and the PMN number were high $\left(351 \mathrm{ng} / \mathrm{ml} \mathrm{sICAM}-1,48 \mathrm{ng} / \mathrm{ml} \mathrm{lL}-6,15.6 \times 10^{9} \mathrm{PMN} / \mathrm{l}\right)$. Antibiotics were given for several weeks and the sICAM-1 concentration decreased to a low level $(56 \mathrm{ng} / \mathrm{ml})$. IL- 6 concentration slightly increased (day $6,60 \mathrm{ng} / \mathrm{ml})$, but then also decreased to a very low level $(0.3 \mathrm{ng} / \mathrm{ml})$. At the same time the number of PMN decreased $\left(3.4 \times 10^{9} \mathrm{PMN} / 1\right.$ on day $6,0.6 \times 10^{9} \mathrm{PMN} / 1$ on day 18). At the last drainage the bacterial culture of the ascites was negative and the number of PMN had further decreased $\left(0.5 \times 10^{9} \mathrm{PMN} / \mathrm{l}\right.$; Fig. 3B).

The ICAM- 1 and IL- 6 concentrations were also measured in drained dialysates of two CAPD patients during an episode of peritoneal infection (patient 3: four times, days $0,1,8,13$ ) and patient 4 : six times, days 0 , $3,6,7,10,12$ ). Patient 3 had an untreated bacterial infection on day 0 (Klebsiella, $\left.1.4 \times 10^{9} \mathrm{PMN} / 1\right)$, the
sICAM- 1 concentration was $3 \mathrm{ng} / \mathrm{ml}$ and the IL-6 concentration $80 \mathrm{ng} / \mathrm{ml}$. On day 1 antibiotics were given and the IL- 6 concentration decreased $(66 \mathrm{ng} / \mathrm{ml})$, and the sICAM-1 concentration $(6 \mathrm{ng} / \mathrm{ml})$ and the number of PMN $\left(3.8 \times 10^{9} \mathrm{PMN} / \mathrm{l}\right)$ increased. On day 8 the sICAM-1 concentration had decreased only slightly, but the IL- 6 concentration $(3 \mathrm{ng} / \mathrm{ml})$ and the number of PMN $\left(0.1 \times 10^{9} \mathrm{PMN} / \mathrm{l}\right)$ had decreased. On day 13 the patient was free of infection (negative culture, $<0.1 \times 10^{9}$ PMN/1), sICAM-1 was not detectable and the IL-6 concentration stayed low ( $3 \mathrm{ng} / \mathrm{ml}$; Fig. $4 \mathrm{~A})$.

Patient 4 had a bacterial infection on day 0 (Enterococcus faecalis, $1.4 \times 10^{9} \mathrm{PMN} / \mathrm{l}$ ) and before antibiotics were given, the sICAM- 1 concentration was $21 \mathrm{ng} / \mathrm{ml}$ and the IL- 6 concentration $12 \mathrm{ng} / \mathrm{ml}$. On day 3 after antibiotics were given, the IL- 6 concentration increased slightly $(13 \mathrm{ng} / \mathrm{ml})$, but sICAM-1 concentration $(9 \mathrm{ng} / \mathrm{ml})$ and also the number of PMNs in the 
dialysates $\left(0.8 \times 10^{9} \mathrm{PMN} / \mathrm{l}\right)$ decreased. Between days 6 and 10 the infection was still present, but the concentration of sICAM-1 and IL- 6 and the number of PMN decreased (day 6: $0.9 \mathrm{ng} / \mathrm{ml}$ sICAM-1, $0.8 \mathrm{ng} / \mathrm{ml} \mathrm{IL-6,}$ $0.5 \times 10^{9} \mathrm{PMN} / \mathrm{l}$; day $7: 0 \mathrm{ng} / \mathrm{ml}$ sICAM-1, $2 \mathrm{ng} / \mathrm{ml} \mathrm{IL-6}$, $0.2 \times 10^{9} \mathrm{PMN} / 1$; day $10: 0 \mathrm{ng} / \mathrm{ml}$ sICAM-1, $0.9 \mathrm{ng} / \mathrm{ml}$ IL-6, $\left.0.1 \times 10^{9} \mathrm{PMN} / \mathrm{l}\right)$. On day 12 the patient was free of infection (negative culture, PMN $<0.1 \times 10^{9}$ ), sICAM- 1 was not detectable and the IL- 6 concentration $(0.8 \mathrm{ng} / \mathrm{ml})$ was also low (Fig. $4 \mathrm{~B})$.

The correlation between SICAM-1, IL- 6 and the number of PMN in the ascites and the drained dialysates in those patients with a peritonitis was for SICAM-1 and PMN $0.7201(P=0.0002)$, for IL-6 and PMN 0.4454 $(P=0.0378)$ and for SICAM-1 and IL-6 0.4800 $(P=0.0238)$.

\section{DISCUSSION}

The present study shows that there are significant differences in the concentrations and patterns of inflammatory products in ascites due to different disorders. Soluble ICAM-1, the eicosanoids PGE $_{2}$ and $\mathrm{LTB}_{4}$ all clearly differentiated between peritoneal cancer and liver cirrhosis: these metabolites were all higher in ascites of patients with peritoneal cancer. Ascitic sICAM-1 and ascitic IL-6 also increased during episodes of peritoneal infection in two patients with SBP as well as in infected dialysates of two CAPD patients.

Soluble ICAM-1 levels were much higher in plasma than in ascites, in contrast to IL-6 levels which were much higher in ascites than in plasma. Soluble ICAM-1 in ascites of all the patients correlated with SICAM-1 in plasma of these patients. The sICAM-1 levels in plasma of patients were significantly higher than the plasma levels of the controls. The cytokines IL-1 $\beta$ and TNF- $\alpha$ were low or not detectable in ascites or plasma of patients with liver cirrhosis, peritoneal cancer or SBP.

\section{Soluble ICAM-1 concentration in ascites and plasma}

Although there were significant differences in concentrations of sICAM- 1 in ascites, in the different disorders plasma levels of sICAM-1 were not significantly different, probably due to the small number of plasma samples in the peritoneal cancer group and the SBP group. Other studies showed that SICAM-1 levels were elevated in sera of patients with different type of diseases in comparison to controls (Rothlein et al., 1991; Sfikakis et al., 1993; Sharief et al., 1992) including acute liver disease (chronic hepatic $\mathrm{C}$ virus infection, Nouri-Aria et al., 1993), chronic liver diseases (primary biliary cirrhosis and primary sclerosing cholangitis, Adams et al., 1992) and patients with different forms of cancer (Banks et al., 1993; Harning et al., 1991). Soluble ICAM-1 is probably released more to the bloodstream circulation than locally within the peritoneal cavity as the sICAM-1 levels in plasma of all the patients was significantly higher than levels in ascites of all the patients. Adhesion to and penetration through the vascular endothelium is a mandatory step for leucocyte migration and accumulation at sites of inflammation. De novo or up-regulated expression of adhesion molecules on sinusoidal lining cells in inflamed liver biopsy specimens indicates that these endothelial cells actively modulate their phenotype in response to environmental factors, thus playing a key role in the recruitment of leucocytes in acute and chronic liver inflammation (Volpes et al., 1992) and probably leading to the release of ICAM-1 locally. Malignant melanomas are usually surrounded by a heavy inflammatory infiltrate; the inflammatory cells often express activation-associated markers (Ralfkiaer et al., 1987) and the malignant melanomas express ICAM-1 (Hansen et al., 1991). An explanation for the significant differences of sICAM-1 concentration in ascites of the different groups in our study could be that cancer cells are also a source of sICAM-1. A study showed that an unstimulated human melanoma cell line expressed ICAM-1 on the cell surface but did not release significant levels of sICAM-1. Stimulation with TNF- $\alpha$, IL- 1 and IFN- $\gamma$, but not IL- 6 , then caused the release of sICAM-1. The same group showed in the same publication that in nude mouse models bearing s.c. human melanoma tumours, the serum contained human sICAM-1 (Giavazzi et al., 1992). These two studies show clearly that only the cancer cells in these models could have been the source of the soluble form of ICAM-1. In humans, cancer cells are probably an important source for the release of SICAM-1 locally into the peritoneal cavity. Assuming that cancer cells are a source of sICAM-1, this may provide cancer cells with additional escape mechanisms, e.g. ineffective recognition of cell surface ICAM-1 by cytotoxic lymphocytes or blocking immune recognition by blocking the ligand for ICAM-1, lymphocyte-functionassociated antigen 1 (LFA-1), on the leucocytes (Springer, 1990; Rothlein et al., 1986).

All our patients with peritoneal cancer had high levels of sICAM-1 in the ascites. As all these patients have late stage cancer, it was not possible to correlate the disease progression of these patients with the sICAM- 1 level in the ascites or plasma of these patients. Other studies did show that the levels of sICAM-1 in 
humans correlated with liver metastasis in a variety of tumours, and with disease progression in melanoma cells (Banks et al., 1993; Harning et al., 1991).

\section{$I L-1, I L-6$ and $T N F-\alpha$ concentrations in ascites and plasma}

In previous studies we isolated $\mathrm{M} \phi$ from ascitic fluid of patients with liver cirrhosis. These M $\phi$ had a high IL-6 production capacity (Pruimboom et al., 1994). The IL-6 levels in the ascites of the patients used for this study were always much higher in the peritoneal cavity than in the plasma, indicating that IL- 6 was produced locally in the peritoneal cavity by $\mathrm{M} \phi$. Endothelial cells are also able to produce IL-6 (Aarden et al., 1991; Jirik et al., 1989). IL-1 $\beta$ and TNF- $\alpha$ were hardly detectable in ascites or plasma of patients with liver cirrhosis, peritoneal cancer and PBS. Other reports, however, show that besides elevated IL-6 levels, elevated IL-I and TNF- $\alpha$ plasma levels were found in patients with ascites caused by liver diseases, in comparison to controls (Khoruts et al., 1991; Tilg et al., 1992). In SBP patients, in comparison to non-infected patients, elevated TNF- $\alpha$ levels in ascites (Deviere et al., 1991) and plasma (Byl et al., 1993) were also found. Similarly to our results, one other report also described significant elevated IL- 6 , but not IL-1 or TNF- $\alpha$ levels in ascites and serum of SBP patients (Propst et al., 1993).

Besides $M \phi$ and endothelium, tumour cells should also be considered as potential sources of IL-6. Some tumour cells have been shown to produce IL-6 (Heinrich et al., 1990; Kawano et al., 1988). IL-6 is a potent growth factor for myeloma/plasmacytoma cells and its deregulated expression may be involved in the oncogenesis of human multiple myelomas (Kishomoto, 1989). In this way IL-6 can be involved in the growth pattern of malignancy.

The liver is an important site of synthesis and is the main clearance organ of circulating cytokines. The rapid hepatic clearance of circulating cytokines may normally constitute an important mechanism limiting the systemic action of cytokines. Lack of hepatic clearance may be one reason for disturbances of the immune system in patients with hepatic cirrhosis (Andus et al., 1991) and probably also in patients with liver metastasis. IL-6 is important in liver diseases, as it induces acutephase protein synthesis, particularly fibrinogen production, in hepatocytes (Kishomoto, 1989). The high IL-6 production during the bacterial infection is probably a direct effect of the bacteria on the macrophages in the peritoneum: lipopolysaccharide (LPS), a bacterial membrane component, is known to be one of the most potent stimuli of M $\phi$ (Lynn \& Golenbock, 1992). Increasing LPS concentrations increase the IL-6 production capacity of human peritoneal $\mathrm{M} \phi$ in vitro (Pruimboom et al., 1994).

\section{Correlation between IL-6 and SICAM-1}

The high sICAM-1 and IL- 6 levels and low IL-1 $\beta$ and TNF- $\alpha$ levels in the patients with ascites could indicate that there is a connection between IL- 6 and sICAM-1: IL-6 could induce ICAM-1 expression and also the release of the soluble form. In an auto-immune mouse model ICAM-1 was newly induced in the hepatic sinusoids of controls by intravenous injection of recombinant mouse IL-6, and elevated production of IL- 6 by hepatic mononuclear cells also correlated with this ICAM-1 expression (Ohteki et al., 1993). However, incubation of cultured monolayers of human endothelial cells with IL-6 did not affect their adhesiveness for human monocytes (Beekhuizen et al., 1991). IL-1 $\alpha / \beta$, INF- $\alpha$ and IFN- $\gamma$, but not IL-6, increase the permeability of human endothelial cells in vitro (BurkeGaffney \& Keenan, 1993).

It has not been shown previously that both SICAM-1 and IL-6 levels in ascites of patients with SBP and in the dialysis fluid of CAPD patients with SBP correlated with episodes of infection. sICAM-I and IL-6 levels were high when the patients had an infection, decreased when antibiotics were given and were hardly detectable when the patients were free of infection.

\section{Eicosanoids in ascites and plasma}

It is not clear why LTB $_{4}$ production is much higher in ascites of the peritoneal cancer group than in the liver cirrhosis group. It is likely that cancer cells in the peritoneal cancer group activate the inflammatory cells to produce $\mathrm{LTB}_{4}$. This elevation may in turn stimulate ICAM-1 expression (Hoit et al., 1993).

The release of the vasodilating agents $\mathrm{PGE}_{2}$ and $\mathrm{PGI}_{2}$ (Goldyne, 1987) could act as mediators involved in the induction of ascites (Hamilton et al., 1982). In patients with a liver disease, endothelial cells, macrophages and hepatocytes or the disability of the liver to clear these vasodilators (Keppler et al., 1985) could be responsible for the $\mathrm{PGE}_{2}$ and $\mathrm{PGI}_{2}$ production. In patients with cancer, the cancer cells themselves could also be responsible for the high concentration of the $P G$ in ascites. A number of experimentally induced tumours in animals, as well as those occurring naturally in humans, have been found to produce high amounts of

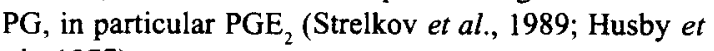
al., 1977).

In conclusion, the levels of SICAM-1, the eicosanoids $\mathrm{LTB}_{4}$ and $\mathrm{PGE}_{2}$ and the protein concentration in ascites are parameters which showed a specific 
disease-related pattern; however, for diagnostic use they may not be suitable as all the parameters of the three different patient groups overlapped. However, as sICAM-1 levels in ascites correlated with sICAM-1 levels in plasma and both sICAM-1 and IL- 6 correlated with episodes of infection (in ascites of patients with SBP and drained dialysates of CAPD patients with SBP),
sICAM-1 and IL-6 seem to be parameters which could be used in the future to monitor patients with SBP.

Acknowledgements - We would like to thank the staff of the following hospitals in Rotterdam for supplying us with ascites: University Hospital Dijkzigt, lkazia Hospital, St Franciscus Hospital and IJsselland Hospital, and Dr M. W. J. A. Fieren, Dr W. A. T. Slieker and Drs M. van Batenburg.

\section{REFERENCES}

Aarden, L., Helle, M., Boeije, L., Pascual-Salcedo, D. \& Groot, E. de (1991). Differential induction of interleukin-6 production in monocytes, endothelial cells and smooth muscle cells. In Cytokines and Inflammation (eds Bienvenu, J. and Fradelize, D.), pp. 15-27. John Libbey Eurotext, Paris.

Adams, D. H., Mainolfi, E., Burra, P., Neuberger, J. M., Ayres, R., Ellias, E. \& Rothlein, R. (1992). Detection of circulating intercellular adhesion molecule- 1 in chronic liver diseases. Hepatology, 16, 810-814.

Andus, T., Bauer, J. \& Gerok, W. (1991). Effects of cytokine on the liver. Hepatology, 13, 364-375.

Andus, T., Gross, V., Holstege, A., Weber, M., Ott, M., Gerok, W. \& Schölmerich, J. (1992). Evidence for the production of high amounts of interleukin- 6 in the peritoneal cavity of patients with ascites. J. Hepatol., 15, 378-381.

Arai, K. I., Lee, F., Miyajima, A., Miyatake, S., Arai, N. \& Yokotai, T.(1990). Cytokines: coordinators of immune and inflammatory responses. $A$. Rev. Biochem., 59, 783-836.

Bac, D. J., Siersema, P. D. \& Wilson, J. H. P. (1993a). Paracentesis. The importance of optimal ascitic fluid analysis. Neth. J. Med., 43, 147-155.

Bac, D. J., Siersema, P. D., Mulder, P. G. H., Marie, S. de \& Wilson, J. H. P. (1993b). Spontaneous bacterial peritonitis: outcome and predictive factors. Eur. J. Gastroenterol. Hepatol., 5, 635-640.

Banks, R. E., Gearin, A. J. H., Hemingway, I. K., Norfolk, D. R., Perren, T. J. \& Selby, P. J. (1993). Circulating intercellular adhesion molecule-1 (ICAM-1), E-selectin and vascular cell adhesion molecule-1 (VCAM-1) in human malignancies. $B r . J$. Cancer, 68, 122-124.

Beekhuizen, H., Corsèl-Tilburg, A. J., Blokland, I. \& Van Furth, R. (1991). Characterization of the adherence of human monocytes to cytokine-stimulated human macrovascular endothelial cells. Immunology, 74, 661-669.

Burke-Gaffney, A. \& Keenan, A. K. (1993). Modulation of human endothelial cell permeability by combinations of the cytokines interleukin-1 $\alpha / \beta$, tumor necrosis factor- $\alpha$ and interferon-gamma. Immunopharmacology, $25,1-9$.

Byl, B., Roucloux, I., Crusiaux, A., Dupont, E. \& Devière, J. (1993). Tumor necrosis factor $\alpha$ and interleukin-6 plasma levels in infected cirrhotic patients. Gastroenterology, 104, 1492-1497.

Devière, J., Content, J., Crusiaux, A. \& Dupont, E. (1991). IL-6 and TNF- $\alpha$ in ascitic fluid during spontaneous bacterial peritonitis. Dig. Dis. Sci., 36, 123-125.

Dustin, M. L., Rothlein, R., Bhan, A. K., Dinarello, C. A. \& Springer, T. A. (1986). Induction by IL-1 and interferon-gamma: tissue distribution, biochemistry, and function of a natural adherence molecule (ICAM-1). J. Immun., 137, $245-254$.

Felver, M. E., Mezey, E., McGuire, M., Mitchell, M. C., Herlong, H. F., Veech, G. A. \& Veech, R. L. (1990). Plasma tumor necrosis factor $\alpha$ predicts decreased long-term survival in severe alcoholic hepatitis. Alcohol. Clin. exp. Res., 14, $255-259$.

Giavazzi, R., Chirivi, G. S., Garofalo, A., Rambaldi, A., Hemingway, I., Pigott, R. \& Gearing, J. H. (1992). Soluble intercellular adhesion molecule 1 is released by human melanoma cells and is associated with tumor growth in nude mice. Cancer Res., 52, 2628-2630.

Goldyne, M. E. (1987). Prostaglandins and other eicosanoids. In Basic and Clinical Pharmacology (ed. Katzung, B. G.), pp. $211-221$. Appleton and Lange Norwalk, Connecticut.

Hamilton, G., Chow Fung Phing, R., Hutton, R. A., Dandona, P. \& Hobbs, K. E. F. (1982). The relationship between prostacyclin activity and pressure in the portal vein. Hepatology, 2, 236-242.

Hansen, N. L., Ralfkiaer, E., Hou-Jensen, K., Thomsen, K., Drzewiecki, K. T., Rothlein, R. \& Vejlsgaard, G. L. (1991). Expression of intercellular adhesion molecule-1 (ICAM-1) in benign naevi and malignant melanomas. Acta. Derm. verereol., 71, 48-51.

Harning, R., Mainolfi, E., Bystryn, J. C., Henn, M., Meruzzi, V. J. \& Rothlein, R. (1991). Serum levels of circulating intercellular adhesion molecule 1 in human malignant melanoma. Cancer Res., 51, 5003-5005.

Heinrich, P. C., Castell, J. V. \& Andus, T. (1990). Interleukin-6 and the acute phase response. Biochem. J., 265, $621-636$.

Holt, W., Anderson, D. C. \& Miyasaka, M. (1993). Role of adhesion glycoproteins in lipid mediator-induced leucocyte adherence and emigration in rat mesenteric venules. Gastroenterology., 10, A807.

Husby, G., Strickland, R. G., Rigler, G. L., Peake, G. T. \& Williams, R. C. (1977). Direct immunological detection of prostaglandin-E and cyclic nucleotides in human malignant tumors. Cancer, 40, 1629-1642.

Jirik, F. R., Podor, T. J., Hirano, T., Kishomoto, T., Loskutoff, D. J., Carson, D. A. \& Lotz, M. (1989). Bacterial lipopolysaccharide 
and inflammatory mediators augment IL-6 secretion by human endothelial cells. J. Immun., 142, 144-147.

Kawano, M., Hirano, T., Matsuda, T., Taga, T., Horii, Y., Iwato, K., Asaoku, H., Tang, B., Tanabe, O., Tanaka, H., Kuramoto, A. \& Kishomoto, T. (1988). Autocrine generation and requirement of BSF-2/lL-6 for human multiple myelomas. Nature, 332 , 83-85.

Keppler, D., Hagmann, W., Rapp, S., Denzlinger, C. \& Koch, H. K. (1985). The relation of leukotrienes to liver injury. Hepatology, 5, 883-891.

Khoruts, A., Stahnke, L., McClain, C. J., Logan, G. \& Allen, J. I. (1991). Circulating tumor necrosis factor, interleukin-1 and interleukin-6 concentrations in chronic alcoholic patients. Hepatology, 13, 267-276.

Kishomoto, T. (1989). The biology of interleukin-6. Blood, 74, 1-10.

Lewis, R. A. \& Austen, K. F. (1984). The biologically active leukotrienes, biosynthesis, metabolism, receptors, functions, and pharmacology. J. clin. Invest., 73, 889-897.

Lynn, W. A. \& Golenbock, D. T. (1992). Lipopolysaccharide antagonists. Immun. Today, 13, 271-276.

McClain, C. J., Cohen, D. A., Dinarello, C. A., Cannon, J. G., Shedlofsky, S. I. \& Kaplan, A. M. (1986). Serum interleukin-1 activity in alcoholic hepatitis. Life Sci., 39, 1479-1485.

Nouri-Aria, K. T., Tibbs, C. J. \& Williams, R. (1993). Soluble intracellular adhesion molecule-l (ICAM-1) levels in chronic HCV infection. J. Hepatol., 18, S27-S28.

Ohteki, T., Okamoto, S., Nakumura, M., Nemoto, E. \& Kumagai, K. (1993). Elevated production of interleukin-6 by hepatic MNC correlates with ICAM-1 expression on the hepatic sinusoidal endothelial cells in autoimmune MRL/lpr mice. Immun. Lett., 36, 145-152.

Oppenheim, J. J., Ruscetti, F. W. \& Faltynek, C. (1991). Cytokines. In Basic and Clinical Immunology (eds Stites, D. P. and Terr, A. I.), pp. 78-100. Lange Medical Publications, Connecticut.

Pattaroyo, M. (1989). Leucocyte adhesion to cells. Molecular basis, physiological relevance and abnormalities. Scand. J. Immun., 30, $29-164$.

Pelletier, G., Briantais, M. J., Seta, N., Lebrun, L., Durand, G. \& Galanaud, P. (1992). Effects of spontaneous bacterial peritonitis on ascitic fluid interleukin-6 and $\alpha_{1}$-acid glycoprotein levels in cirrhotic patients. Eur. J. Gastroenterol. Hepatol., 4, $295-300$.

Pober, J. S., Gimbrone, M. A., Lapierre, L. A., Mandrick, D. L., Fiers, W., Rothlein, R. \& Springer, T. A. (1986). Overlapping patterns of activation of human endothelial cells by interleukin-1, tumor necrosis factor, and immune interferon. $J$. Immun., 137, 1893-1896.

Propst, T., Propst, A., Herold, M., Shauer, G., Judmaier. G., Braunsteiner, H., Stöffler, G. \& Vogel, W. (1993). Spontaneous bacterial peritonitis is associated with high levels of interleukin-6 and its secondary mediators in ascitic fluid. Eur. J. clin. Invest., 23, 832-836.

Pruimboom, W. M., Dijk van J. A. P. M., Tak, C. J. A. M., Bonta, I. L., Wilson, J. H. P. \& Zijlstra, F. J. (1994). Production of inflammatory mediators by human macrophages. Prostaglandin Leukotr, EFA, 50, 183-192.

Ralfkiaer, E., Hou-Jensen, K., Gatter, K. C., Drzewiecke, K. T. \& Mason, D. Y. (1987). Immunohistological analysis of the lymphoid infiltrate in cutaneous malignant melanomas. Virchows Arch. A., 410, 355-361.

Rothlein, R., Dustin, M. L., Marlin, S. D. \& Springer, T. A. (1986). A human intercellular adhesion molecule (ICAM-1) distinct from LFA-1. J. Immun., 137, 1270-1274.

Rothlein, R., Mainolfi, E. A., Czajkowski, M. \& Marlin, D. (1991). A form of circulating ICAM-1 in human serum.J. Immun., 147, 3788-3793.

Sfikakis, P. P., Tesar, J., Baraf, H., Lipnick, R., Klipple, G. \& Tsokos, C. (1993). Circulating intercellular adhesion molecule-1 in patients with systemic sclerosis. Clin. Immun. Immunopath., 68, 88-92.

Sharief, M. K., Ciardi, M., Noori, M. A., Thompson, E. J., Salotti, A., Sorice, F., Rossi, F. \& Cirelli, A. (1992). Free circulating ICAM-1 in serum and cerebrospinal fluid of HIV-1 infected patients correlate with TNF- $\alpha$ and blood-brain barrier damage. Med. Inflamm., 1, 323-328.

Springer, T. (1990). Adhesion receptors of the immune system. Nature, 346, 425-434.

Strelkov, A. B., Fields, A. L. \& Baracos, V. E. (1989). Effects of systemic inhibition of prostaglandin production on protein metabolism in tumor-bearing rats. Am. J. Physiol., 257, C261-C269.

Temponi, M., Romano, G., D'Urso, C. M., Wang, Z., Kekish, U. \& Ferone, S. (1988). Profile of intercellular adhesion molecule-1 (ICAM-1) synthesized by human melanoma cell lines. Sem. Oncol., 15, 595-607.

Tilg, H., Wilmer, A., Vogel, W., Herold, M., Nölchen, B., Judmaier, G. \& Huber, C. (1992). Serum levels of cytokines in chronic liver diseases. Gastroenterology, 103, 264-274.

Vas, S. I. (1989). Peritonitis. In Peritoneal Dialysis (ed. Nolph, K.), pp. 261-288. Kluwer Academic, Dordrecht.

Volpes, R., Oord van den, J. J. \& Desmet, V. J. (1992). Vascular adhesion molecule in acute and chronic liver inflammation. Hepatology, 15, 269-275. 